\title{
MINERALOGY OF THE MANTLE XENOCRYSTS FROM KL-1 (KELSEY LAKE) KIMBERLITE PIPE, COLORADO
}

\author{
IGOR VICTOROVICH ASHCHEPKOV ${ }^{1}$, NIKOLAI VASILIEVICH VLADYKIN ${ }^{2}$, ROGER H. MITCHELL ${ }^{3}$, \\ HOWARD COOPERSMITH ${ }^{3}$, GARANIN VICTOR GENADIEVICH ${ }^{1}$, ANATOLIY ILIYCH SAPRYKIN ${ }^{1}$, OLGA \\ STEPANOVNA KHMELNIKOVA ${ }^{1} \&$ GENADIY NIKITOVICH ANOSHIN ${ }^{1}$
}

\begin{abstract}
Garnets, clinopyroxenes, spinels and ilmenites from the concentrate of KL-I kimberlite pipe, (Kelsey lake) Front Range group, were analyzed to reconstruct the mantle section and the processes in the mantle beneath Wyoming craton. Garnets show a trend up to $12 \% \mathrm{Cr} \mathrm{O}_{3}$ within the lherzolite field with decreasing frequency for deeper garnets. Several $\mathrm{TiO}$, trends passing through all the $\mathrm{Cr}_{3} \mathrm{O}_{3}$ range suggest separate pulses of melt percolation. Their amount coincides with the amount of groups for $\mathrm{Cr}$ - diopsides. Deformed garnets - clinopyroxene intergrowths higher in TiO are more heated (to $40-45 \mathrm{mv} / \mathrm{m}^{2}$ ) then individual grains. Ilmenites showing a long (polybaric) differentiation trend became more Cr-rich but spinels are essentially more Ti rich Al-rich (shallow level) varieties. Trace elements for Cr-diopsides suggest participation of subduction- related material with high $\mathrm{U}$ content increase and HREE decrease according to AFC with garnet dissolution.
\end{abstract}

INTRODUCTION The concentrate of deep-seated minerals from the Colorado kimberlite pipe KL-1 (Kelsey Lake) was analyzed by EPMA in UIGGM SD RAS.

RESULTS Garnets (fraction +1 ) from this pipe reveal a long trend on the $\mathrm{Cr}_{2} \mathrm{O}_{3}-\mathrm{CaO}$ diagram (up to $12 \% \mathrm{Cr}_{2} \mathrm{O}_{3}$ ). (Fig. 1) (Table.1).

From the beginning to $1 \%$ the pyropes with the elevated Fe\# correspond to pyroxenites. The $1-3 \% \mathrm{Cr}_{2} \mathrm{O}_{3}$ interval parallel to $\mathrm{Cr}$ axis refers to thezolites from $\mathrm{Ga}-\mathrm{Sp}$ facies. In this diagram the pyropes from $4 \% \mathrm{Cr}_{2} \mathrm{O}_{3}$ show a joint rise of the $\mathrm{Cr}_{2} \mathrm{O}_{3}-\mathrm{CaO}$ crossing the common lherzolite trend (Sobolev 1974). Variable inclination of garnet trends is a common feature found for kimberlite garnets in S.Africa (Burgess \& Harte 2000), Jericho pipe (Kopylova et al. 1999) and Aldan kimberlites (Ashchepkov et al. 2000). This feature is evidently seen in garnet diagrams from the nearby located Iron Mountain kimberlite (Hausel 1998, WSGS web page) that have high proportion of G10 garnets possibly analyzed from a finer fraction.

Presence of separate clots (5) in linear trend is determined by capturing from the separate pressure intervals and mantle sections since the $\mathrm{Cr}$ - content is variable. Deviation to lower $\mathrm{CaO}$ values corresponds to the deformed garnet grains found in intergrowths with clinopyroxenes and spinels. They are also more ferriferous and their Fe\# can't be explained by heating. (Fig.1). The frequency of the $\mathrm{Cr}$ - in garnets decreases in hyperbolic function reflecting the amount of the deep peridotite xenogenic material or it may be explained by the dissolving or lost of the deeper garnets or loss during magma upwelling. The $\mathrm{Cr}$-Fe-Ti relations (Fig. I) suggests that even in the same pressure interval the lithology of the mantle substrate was not homogeneous and the rocks from the same interval were probably modified by several stages of melt percolation $(\mathrm{Cr}-\mathrm{Ti}$ trends). Relative amount of depleted rocks commonly rises with the depth. Cr-rich subcalcic garnet usually refer to depleted harzburgite affinity. But in this concentrate deformed garnets with intermediate $\mathrm{Cr}$ concentration found in intergrowth with spinels have lower $\mathrm{CaO}$ and $\mathrm{TiO}_{2}$. They show a flat $\mathrm{FeO}$ trend on the $\mathrm{Cr}_{2} \mathrm{O}_{3}-\mathrm{FeO}$ diagram and are derived from the heated lherzolites relatively enriched in $\mathrm{Fe}$ but low in Ti.

Clinopyroxenes found in concentrate occurs in two main varieties. Those found in intergrowth with the fractured garnets are enriched in the $\mathrm{Na}_{2} \mathrm{O}, \mathrm{Al}_{2} \mathrm{O}_{3}, \mathrm{Cr}_{2} \mathrm{O}_{3}$ and $\mathrm{FeO}$. Individual bright grains of $\mathrm{Cr}$-diopsides have relatively low concentration of these components but higher $\mathrm{TiO}_{2}$ content (Fig. 2)(Table.1).

Ilmenites from this pipe have $\mathrm{Ti}$ values that sometimes exceed the 1.0 in structural formula (Fig. 3, Table 1). Most of larger ilmenites contain irregular rutile exsolutions. These ilmenites came from desintegrated larger polycrystalline nodules (5-3 mm or more). Those polycrystalline fine grain aggregates sometimes include rounded rutile grains in intergranular space between polygonal ilmenites. More rarely these aggregates contain apatite and perovskite. One quartz grain (coesite originally) was found in contact with ilmenites.

In the variation diagrams at least 3-4 groups may be found judging on $\mathrm{Ni}, \mathrm{Al}$ and $\mathrm{Cr}$ content. Trends with the different $\mathrm{Al}_{2} \mathrm{O}_{3}$ concentration suggest the differentiation of the liquid derived different proportion of garnets. Different $\mathrm{Cr}_{2} \mathrm{O}_{3}$ enrichment suggests diverse degree of contamination in wall rock peridotites and possibly varying lithology. Polycrystalline aggregates containing garnets and essential amount of serpentine have very high $\mathrm{Cr}_{2} \mathrm{O}_{3}$ concentration in ilmenite ( $>7 \%)$ and garnet $(\sim 11 \%)$. Two serpentine varieties - with 
high $(56 \%)$ and low ( 40\%) $\mathrm{SiO}_{2}$ content substitute Opx and $\mathrm{Ol}$ respectively (Table 2.). Origin of other $\mathrm{Cr}$ - bearing groups is problematic. Intermediate compositions between rutiles and common Ilnenites are explained by tiny exsolutions (Fig. 3)

Chromites from concentrate of this pipe reveal two main modes (Fig. 4, Table 1), but a more detailed histogram shows that there are at least $4-5$ peaks and possibly capturing intervals. The highest contents of $\mathrm{Cr}_{2} \mathrm{O}_{3}(65-50 \%)$ probably refer to the minerals entrained from the deeper part of the mantle section (50-70 kbar) while $30-50 \% \mathrm{Cr}_{2} \mathrm{O}_{3}$ should come from the rocks from the middle part, which refer to $3-5 \%$ $\mathrm{Cr}_{2} \mathrm{O}_{3}$ in garnets locating in the beginning of the ascending $\mathrm{Cr}_{2} \mathrm{O}_{3}-\mathrm{CaO}$ trend for the pyropes. The $\mathrm{Ti}$ enrichment rise in the less chromian spinels, which may suggest the evolution of parental melts and enrichment by metasomatic agents in the rising system. The chromites found in the intergrowth with garnets are located exactly on the mantle array and shows rather restricted compositional range $\left(55-60 \% \mathrm{Cr}_{2} \mathrm{O}_{3}\right)$ that corresponds here to $5-7 \%$ in coexisting garnets.

TP conditions for mantle peridotites were determined using clinopyroxene thermobarometry (Nimis \& Taylor 2000) and new Jd-Di barometer (Ashchepkov 2001). Separate grains of $\mathrm{Cr}$ - diopsides are located close to $35 \mathrm{mv} / \mathrm{m}^{2}$ and between $35-40$ $\mathrm{mv} / \mathrm{m}^{2}$ geotherms within the $30-50 \mathrm{kbar}$ interval, but the clinopyroxenes in intergrowths with garnets produce the more heated branch (or branches) close to $45 \mathrm{mv} / \mathrm{m}^{2}$. It suggests also at least two heating events which coincides with the amount of trends for Cpx and garnets (Fig. 5).

Trace elements determined by LAM ICP MS for four clinopyroxenes demonstrate common REE patterns for lithospheric mantle peridotites patterns with high $\mathrm{La} / \mathrm{Yb}_{n}$ ratios and divergent HREE. Trace element spidergram demonstrate no strong minima in HREE except for Ta and smaller for $\mathrm{Nb}$ but they reveal evident peak in $\mathrm{U}, \mathrm{Ba}, \mathrm{Sr}$, which is typical for the subduction processes and was determined for mantle peridotites from Somerset island kimberlite (Schmidberger \& Francis 2001) (Fig. 6, Table 3). Some fluctuations near Eu in one Cpx and some other minerals may suggest participation of the subducted material in melting and pyroxenite generation. Pyroxene found in intergrowth with garnets reveal lower HREE and lack of $\mathrm{Sr}$ and other peaks, which suggest the dissolution of garnet possibly by $\mathrm{AFC}$ process.

CONCLUSIONS Mantle section beneath the pipe Kl-1 was subjected to several (at least two) stages of melt percolation that produced also the heating of mantle column. The earliest was followed by Ti-enrichment in minerals and should be produced by plume- related melts while the latest was followed by the $\mathrm{Na}, \mathrm{Al}, \mathrm{Cr}$ enrichment in pyroxenes and deformations in garnets. This section has no sheared lherzolites typical for the Lesotho (Nixon \& Boyd 1973) or Udachnaya pipe (Boyd et al. 1997). It consists from 3 or 4 major units (probably $\mathrm{Pxt}+\mathrm{Ga}-$ SpLhz - Ga-Lhz+deplLhz -Ga-Lhz+deformed Lhz + Hrz -Lhz $+\mathrm{Ilm}-\mathrm{Hrzb}$ ). It is nearly continuously captured by the host kimberlites but the main portion of xenoliths was carried from 30-50 kbar interval where the lenses of coarse eclogite - like pyroxenites similar to the mantle beneath Jericho pipe (Kopylova et al. 1999), Chompolo field (Ashchpekov et al. 2000), and Aldan should exist. Subduction - related material participated in generation of Al-rich $\mathrm{Cr}$ - bearing pyroxenites and melt that produced the megacrysts .

\section{References}

Ashchepkov I., Vladykin N., Ovchinnikov Yu., Anoshin G., Gerasimov P., Saprykin A. 2000. Thermal Gradient, Mantle Layering and Geochemistry beneath Aldan Shield According to the Kimberlitic Deep Seated Disintegrated Inclusions. J. Confer. Abstr., v.5/2:162-163

Ashchepkov I.V. 2001. Clinopyroxene Jd barometer for mantle peridotites and eclogites and thermal conditions of the lithospheric keels of cratons and their surroundings. Abstracts of annual GSA meeting, Boston 2001. November. Abstract ID 11658 .

Boyd F.R., Pokhilenko N.P., Pearson D.G., Mertzman S.A., Sobolev N.V., Finger L.W. 1997. Composition of the Siberian cratonic mantle: evidence from Udachnaya peridotites xenoliths. Contrib. Mineral. Petrol., 128:228-246.

Burgess R. \& Harte B. Tracing Lithosphere Evolution through the Analysis of Heterogeneous G9/G10 Garnets in Peridotite xenoliths. I Major Element Chemistry. Proceedings of the VII International Kimberlite Conference. The P.H. Nixon volume. Pp.61-80.

Hausel W.D. 1998. Diamonds and mantle source rocks in the Wyoming Craton, with a discussion of other US occurrences: Wyoming State Geological Survey Report of Investigations 53, 93 p.
Kopylova M.G., Russell J.K., Cookenboo H. 1999. Petrology of peridotite and pyroxenite xenoliths from the Jericho kimberlite: Implications for the thermal state of the mantle beneath the Slave craton, northern Canada. J. Petrol., 40:79-104.

Nixon P.H. \& Boyd F.R. 1973. Petrogenesis of the granular and sheared ultrabasic nodule suite in kimberlite. In: P.H. Nixon (ed.) Lesotho Kimberlites. Cape and Transvaal, Cape Town, pp. 48-56.

Schmidberger S. S. \& Francis D. 2001. Constraints on the Trace Element Composition of the Archean Mantle Root beneath Somerset Island, Arctic Canada. J. Petrology., 42:1095-1117.

Sobolev N.V. 1974. Deep-Seated Inclusions in Kimberlites and the Problem of the Composition of the Upper Mantle (in Russian). Nauka Press, Novosibirsk, 264 pp. [English Translation (1977), ed. by F.R. Boyd, American Geophysical Union, Washington, DC, 279 pp.]

Ryan C.G., Griffin W.L., Pearson N. 1996. Garnet Geotherms: a technique for derivation of P-T data from Cr-pyrope garnets. J. Geophys. Res., 101:5611-5625

Manuscrito NB-34

Recebido em 18 de novembro de 2001 Revisão dos autores em 27 de dezembro de 2001 Revisão aceita em 29 de dezembro de 2001 


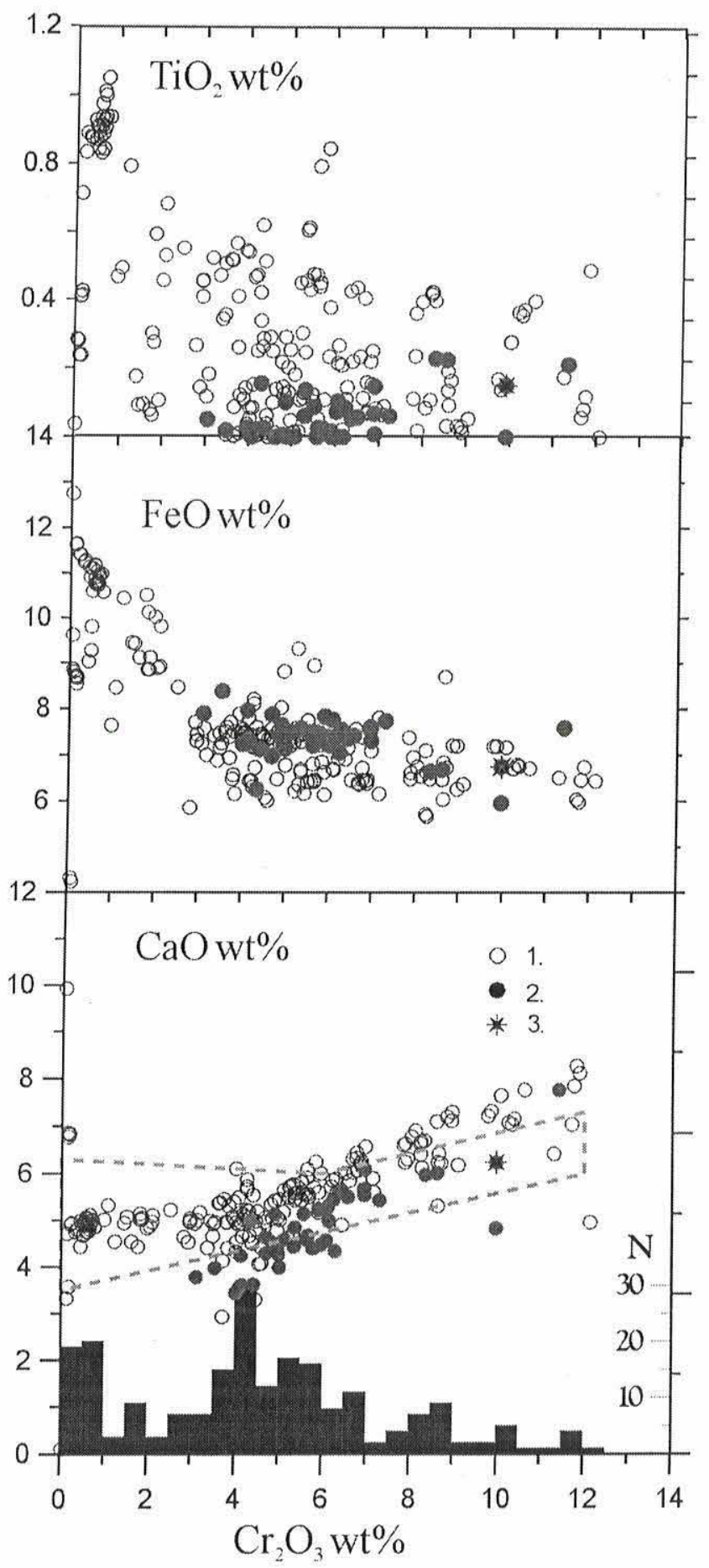

Figure $\mathrm{I}-\mathrm{Cr}_{2} \mathrm{O}_{3}-\mathrm{CaO}-\mathrm{FeO}-\mathrm{TiO}_{2}(\mathrm{wt} \%)$ plots and $\mathrm{Cr}$ frequency histograms for the garnets from Kl-I pipe. Iseparate grains; 2. - intergrowths with clinopyroxenes and garnets; 3.garnet from Ilm-serpentine nodules.

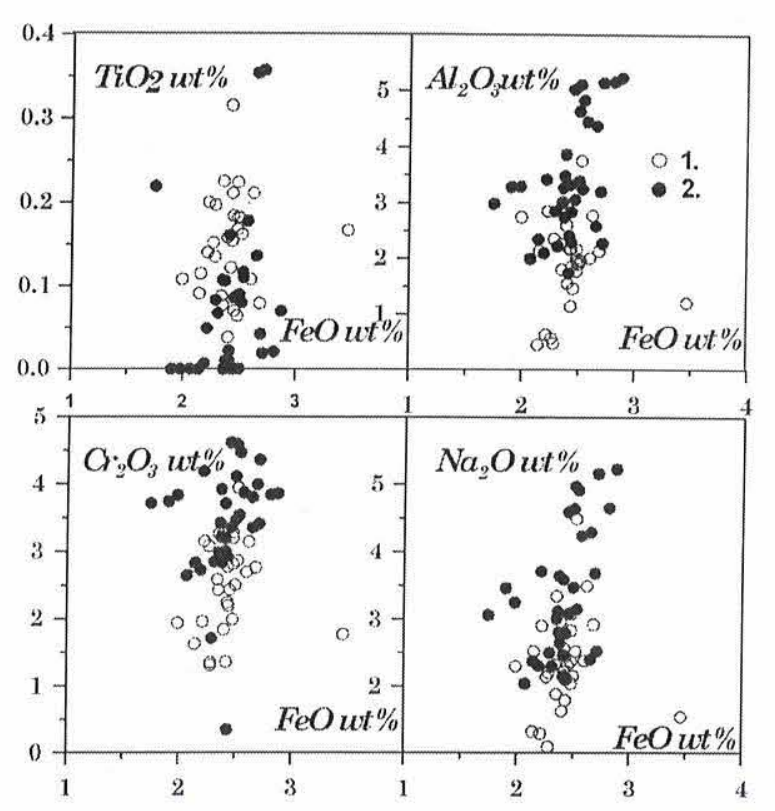

Figure 2 - Composition of Ilmenites from Kl-1 pipe and the frequency histogram for major components. Solid dots intergrowth, open dots - individual grains.

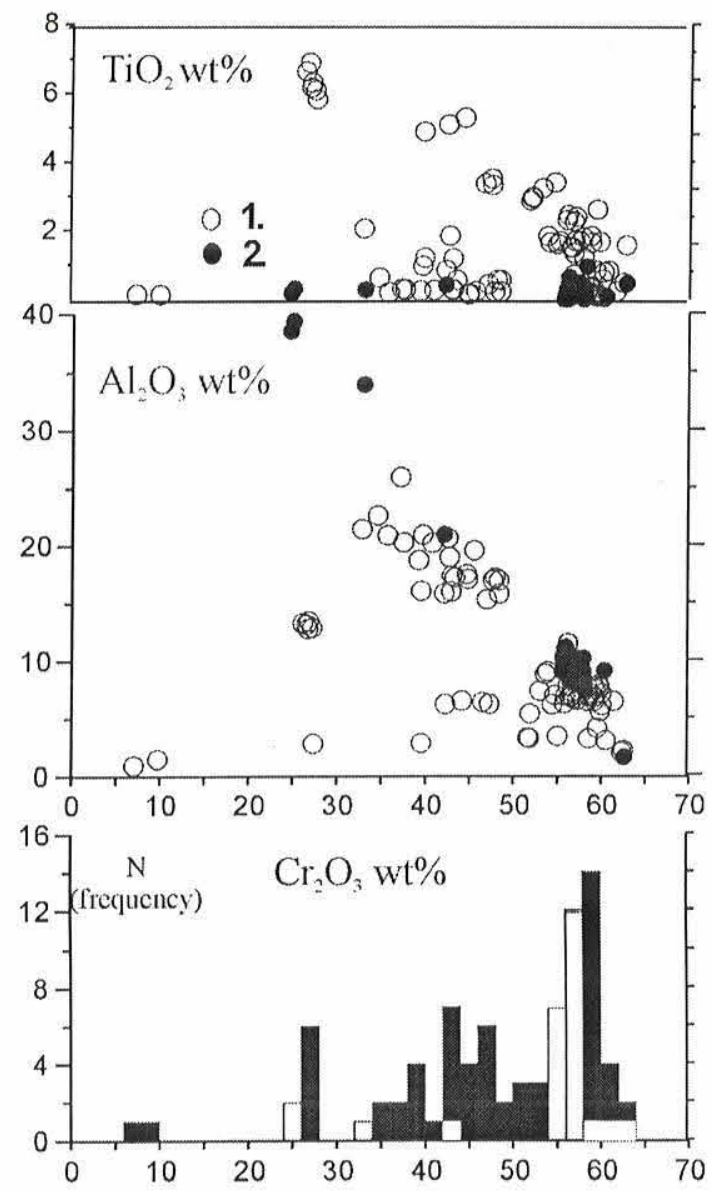

Figure 3 - Composition of $\mathrm{Cr}$ - spinels from $\mathrm{Kl}$ - $\mathrm{I}$ pipe, and frequency histograms for $\mathrm{Cr}_{2} \mathrm{O}_{3}$. 1. Separate spinels; 2. intergrowths with Cpx and Gar. 


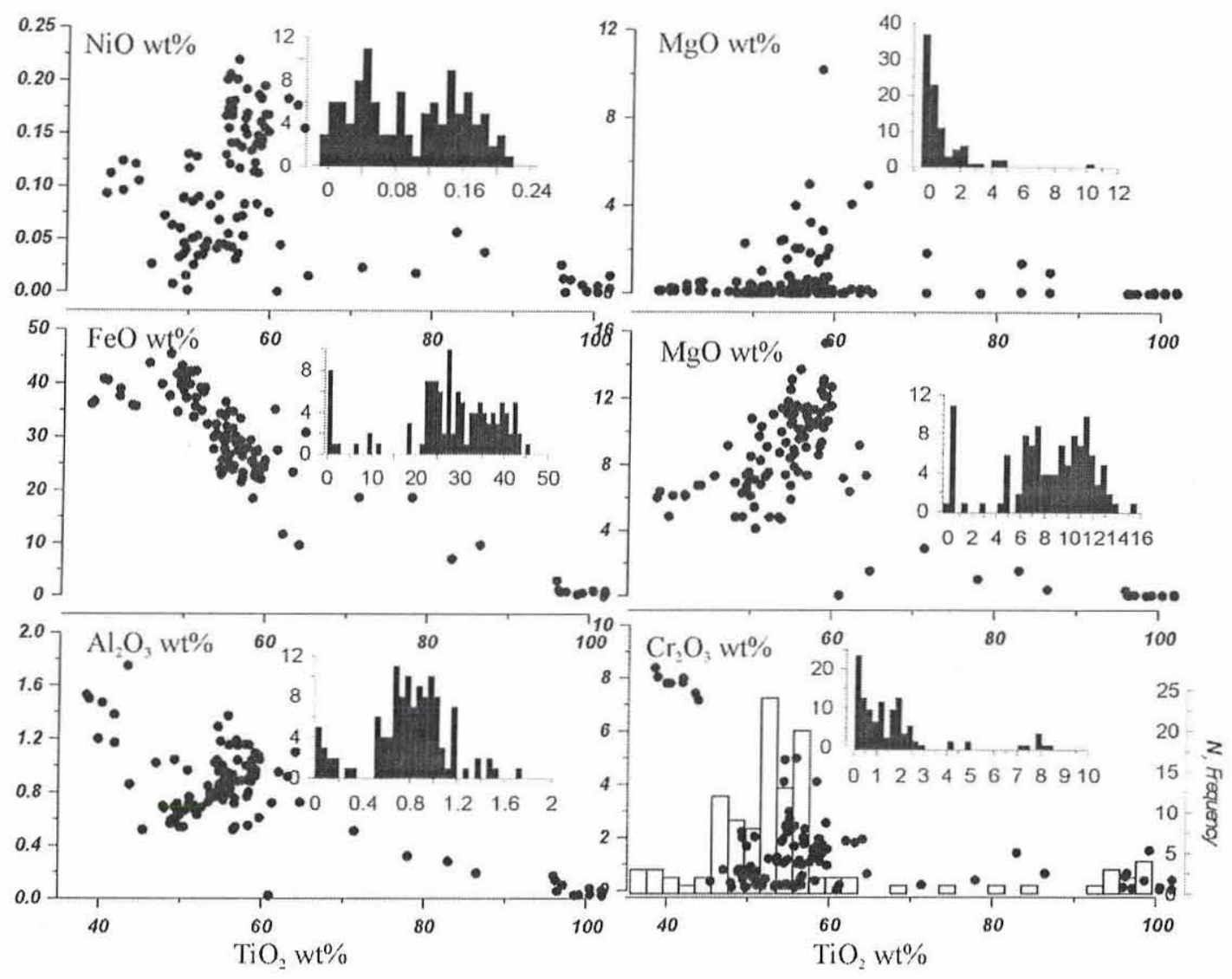

Figure 4 - Variations of the clinopyroxenes from Kl-I pipe. I-2 the same as for Fig.3.

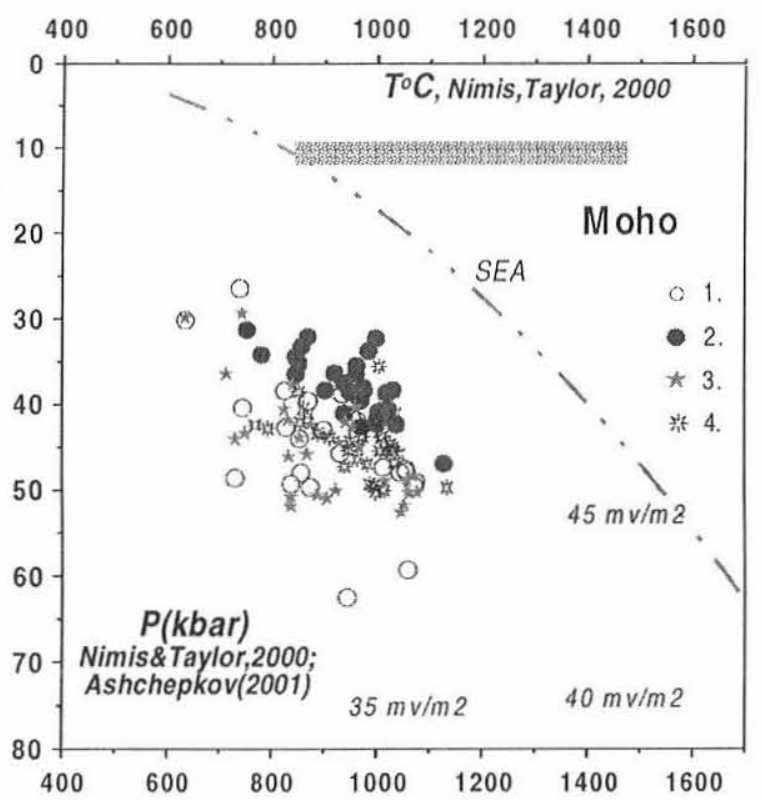

Figure 5 - TP plot for the clinopyroxenes detemined by Nimis and Taylor, 2001 method: 1. separate grains; 2 integrowths; determined by the Jd-Di barometer Ashchepkov, 2001. 3- single grains; 4-intergrowths. 

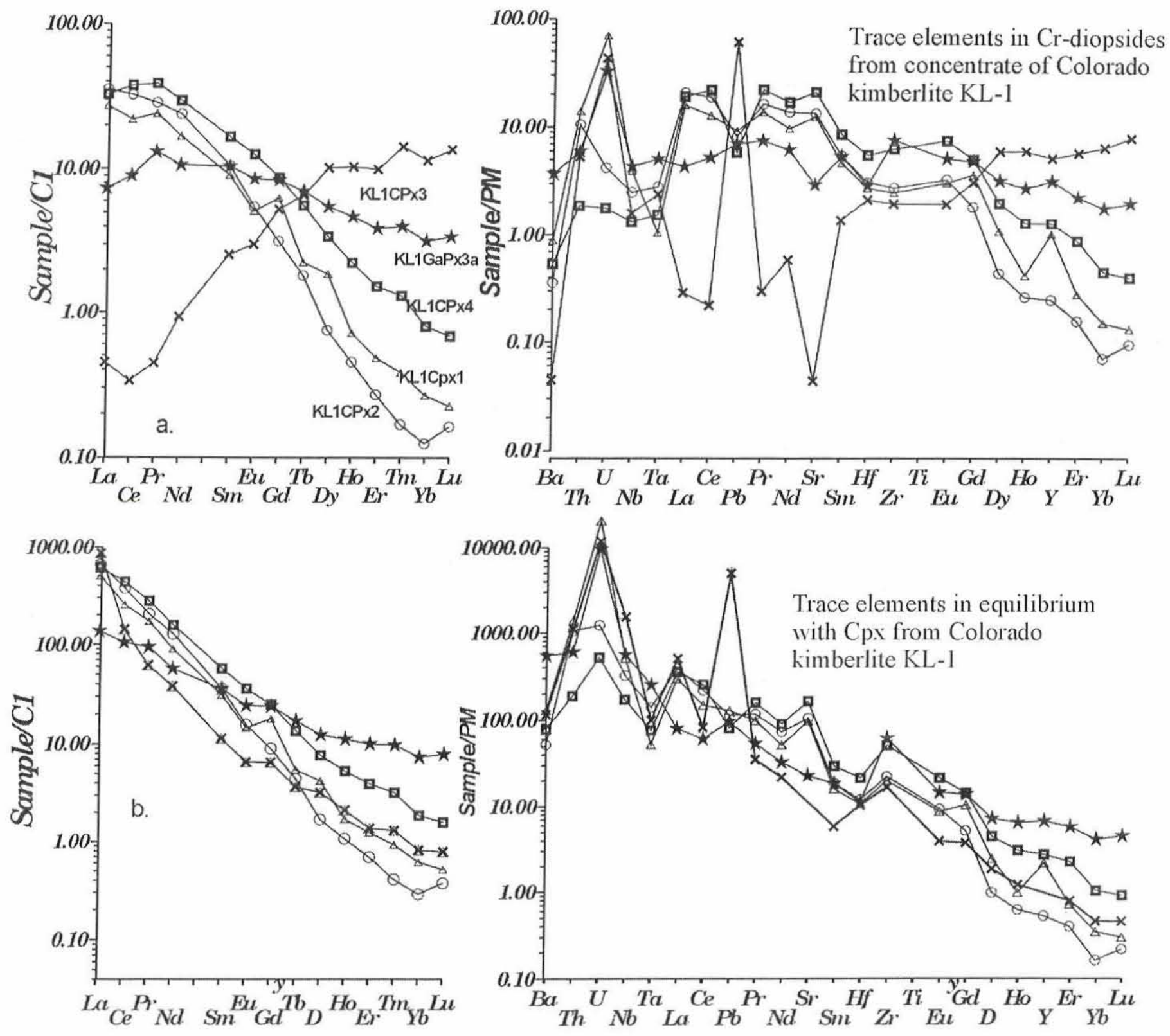

Figure 6-TRE patterns for the clinopyroxenes and some garnets in intergrowth with Cpx and Spinels and TRE patterns for the melts parental for these phases. 
Table 1. Representative analyses of the minerals from the Kl-I pipe, Colorado. Separate grains.

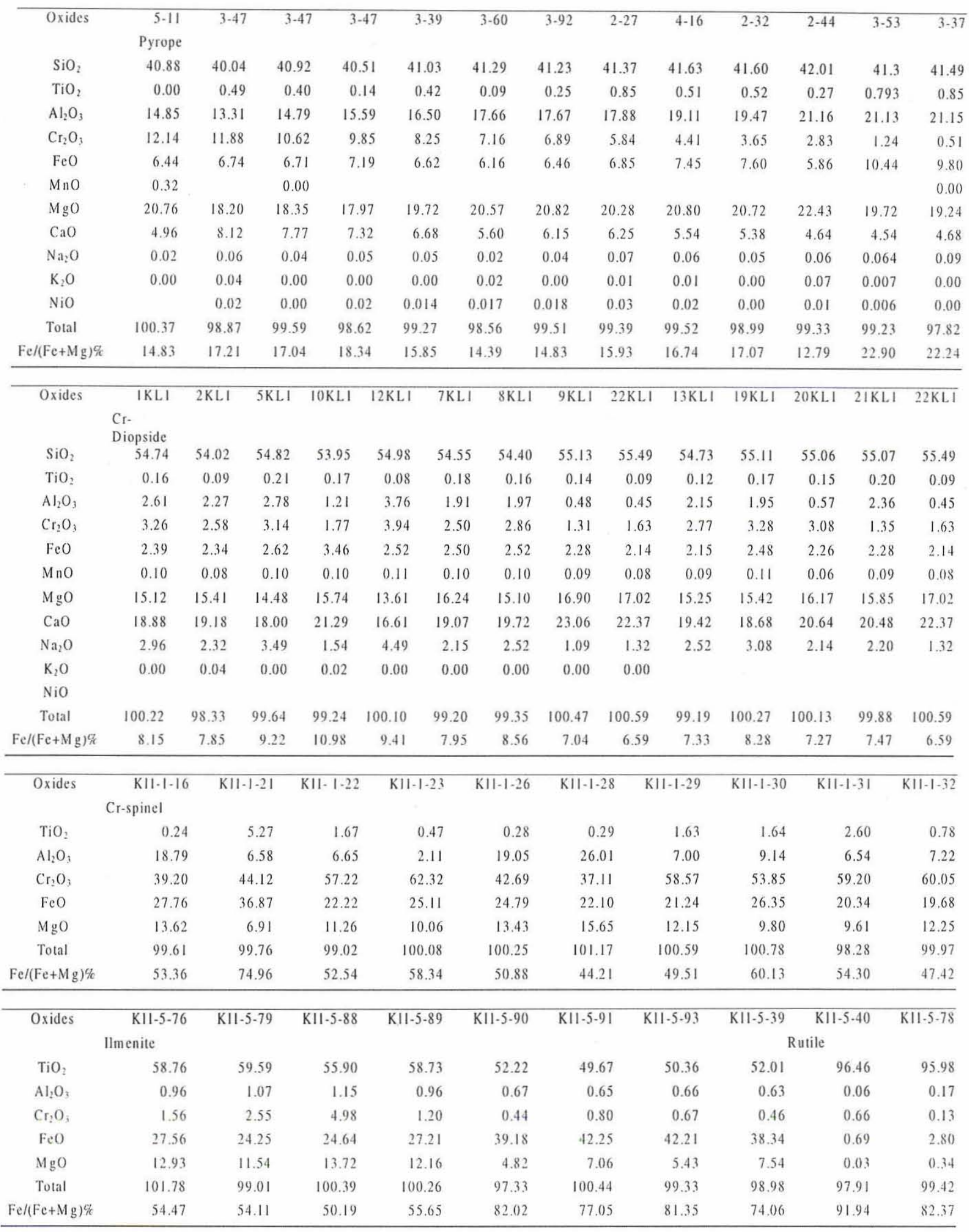


Igor Victorovich Ashchepkov et al.

Table 2. Representative analyses of the minerals from the $\mathrm{Kl}-\mathrm{I}$ pipe, Colorado. Intergrowths.

\begin{tabular}{|c|c|c|c|c|c|c|c|c|c|c|}
\hline \multirow[t]{2}{*}{ Oxides } & \multirow{2}{*}{$\begin{array}{r}\text { KII-33 } \\
\text { Cpx }\end{array}$} & \multicolumn{3}{|c|}{ KII-37 } & \multicolumn{3}{|c|}{ KII-39 } & \multirow{2}{*}{$\begin{array}{r}\text { KII-48 } \\
\text { Cpx }\end{array}$} & \multicolumn{2}{|c|}{ KII-45 } \\
\hline & & Gar & Sp & Cpx & Gar & $\mathrm{Ga}$ & $\mathrm{CPx}$ & & $\mathrm{Ga}$ & Cpx \\
\hline $\mathrm{SiO}_{2}$ & 55.33 & 42.36 & 0.05 & 54.24 & 41.74 & 41.71 & 55.29 & 54.25 & 40.78 & 54.19 \\
\hline $\mathrm{TiO}_{2}$ & 0.07 & 0.02 & 0.93 & 0.36 & 0.22 & 0.01 & 0.05 & 0.14 & 0.08 & 0.02 \\
\hline $\mathrm{Al}_{2} \mathrm{O}_{3}$ & 5.25 & 21.00 & 7.63 & 2.28 & 17.11 & 18.51 & 3.43 & 4.39 & 18.46 & 3.33 \\
\hline $\mathrm{Cr}_{2} \mathrm{O}_{3}$ & 3.86 & 3.54 & 58.08 & 3.41 & 8.62 & 6.96 & 4.19 & 3.80 & 6.28 & 3.71 \\
\hline $\mathrm{FeO}$ & 2.87 & 8.39 & 19.41 & 2.71 & 6.69 & 7.31 & 2.21 & 2.65 & 7.55 & 2.41 \\
\hline $\mathrm{MnO}$ & 0.10 & 0.63 & 0.63 & 0.07 & 0.39 & 0.50 & 0.06 & 0.10 & 0.55 & 0.07 \\
\hline $\mathrm{MgO}$ & 12.44 & 20.48 & 12.95 & 15.93 & 20.12 & 19.43 & 13.97 & 13.45 & 20.32 & 14.21 \\
\hline $\mathrm{CaO}$ & 15.06 & 3.97 & 0.00 & 18.75 & 6.01 & 6.08 & 17.64 & 15.11 & 4.34 & 17.52 \\
\hline $\mathrm{Na}_{2} \mathrm{O}$ & 5.23 & 0.06 & 0.04 & 2.52 & 0.04 & 0.03 & 3.71 & 4.29 & 0.09 & 3.59 \\
\hline Total & 100.21 & 100.44 & 99.72 & 100.26 & 100.95 & 100.53 & 100.55 & 98.17 & 98.46 & 99.06 \\
\hline $\mathrm{Fe} /(\mathrm{Fe}+\mathrm{Mg}) \%$ & 11.46 & 18.69 & 45.68 & 8.71 & 15.72 & 17.43 & 8.15 & 9.96 & 17.25 & 8.69 \\
\hline \multirow[t]{2}{*}{ Oxides } & $\mathrm{K} I \mathrm{I}-45$ & $\mathrm{KII}-46$ & KII-46 & \multicolumn{2}{|r|}{ KII-88 } & \multicolumn{2}{|c|}{$\mathrm{K} 1182$} & \multicolumn{3}{|c|}{ K11-85 } \\
\hline & $\mathrm{Ga}$ & $\mathrm{Cpx}$ & Gar & Sp & $\mathrm{Ilm}$ & $\mathrm{Ga}$ & $Q$ & $\mathrm{Ilm}$ & $\mathrm{Ilm}$ & Rut \\
\hline $\mathrm{SiO}_{2}$ & 41.27 & 54.32 & 41.14 & 0.78 & 0.13 & 41.04 & 98.25 & 0.30 & 0.26 & 0.85 \\
\hline $\mathrm{TiO}_{2}$ & 0.02 & 0.00 & 0.00 & 0.02 & 56.98 & 0.15 & 0.02 & 56.79 & 55.96 & 97.19 \\
\hline $\mathrm{Al}_{2} \mathrm{O}_{3}$ & 18.94 & 3.28 & 19.11 & 9.69 & 0.83 & 15.81 & 0.47 & 1.10 & 0.92 & 0.10 \\
\hline $\mathrm{Cr}_{2} \mathrm{O}_{3}$ & 5.78 & 3.42 & 5.64 & 55.67 & 1.80 & 9.97 & 0.02 & 1.72 & 0.14 & 0.05 \\
\hline $\mathrm{FeO}$ & 7.47 & 2.36 & 7.21 & 20.07 & 26.99 & 6.75 & 0.07 & 29.12 & 31.98 & 0.41 \\
\hline $\mathrm{MnO}$ & 0.51 & 0.09 & 0.45 & 0.72 & 0.84 & 0.43 & 0.02 & 1.65 & 0.39 & 0.03 \\
\hline $\mathrm{MgO}$ & 20.69 & $\quad 14.42$ & 20.39 & 11.23 & 11.87 & 19.09 & 0.02 & 7.92 & 9.37 & 0.11 \\
\hline $\mathrm{CaO}$ & 4.40 & 17.11 & 4.58 & 0.04 & & 6.24 & 0.02 & & & 0.27 \\
\hline $\mathrm{Na}_{2} \mathrm{O}$ & 0.06 & 3.12 & 0.02 & 0.05 & & 0.036 & 0.02 & & & 0.14 \\
\hline Total & 99.14 & 98.12 & 98.54 & 98.26 & 99.43 & 99.52 & 98.92 & 98.60 & 99.01 & 99.14 \\
\hline $\mathrm{Fe} /(\mathrm{Fe}+\mathrm{Mg}) \%$ & 16.85 & 8.41 & 16.56 & 50.08 & 56.06 & 16.56 & 70.95 & 67.34 & 65.69 & 67.39 \\
\hline
\end{tabular}


Table 3 - Composition of major and trace elements from the clinopyroxenes and garnet from KL-l kimberlite pipe Colorado. Note. Major components are determined on CamebaxMicro operator (O.S. Khmelnikova). TRE by LAM ICP MS, analyst Garanin V.G., Analytic Center UIGGM, SD RASC

\begin{tabular}{|c|c|c|c|c|c|c|}
\hline & $12 K L 1$ & $14 K L 1$ & $20 K L 1$ & $48 K L 1$ & $48 K L 1$ & $72 K L 1$ \\
\hline & $C p x$ & $C p x$ & $C p x$ & $C p x$ & $\begin{array}{l}\text { Garnet( } \\
\text { kel) }\end{array}$ & Garnet \\
\hline $\mathrm{SiO} 2$ & 54.98 & 54.72 & 55.06 & 54.25 & 40.78 & 40.2 \\
\hline $\mathrm{TiO} 2$ & 0.08 & 0.22 & 0.15 & 0.14 & 0.08 & 0.21 \\
\hline$A l 2 O 3$ & 3.76 & 1.78 & 0.57 & 4.39 & 18.46 & 14.25 \\
\hline $\mathrm{Cr} 2 \mathrm{O} 3$ & 3.94 & 3.20 & 3.08 & 3.80 & 6.28 & 11.41 \\
\hline $\mathrm{FeO}$ & 2.52 & 2.48 & 2.26 & 2.65 & 7.55 & 7.59 \\
\hline $\mathrm{MnO}$ & 0.11 & 0.11 & 0.06 & 0.10 & 0.55 & 0.475 \\
\hline $\mathrm{MgO}$ & 13.61 & 16.48 & 16.17 & 13.45 & 20.32 & 17.42 \\
\hline $\mathrm{CaO}$ & 16.61 & 18.79 & 20.64 & 15.11 & 4.34 & 7.77 \\
\hline $\mathrm{Na} 2 \mathrm{O}$ & 4.49 & 2.37 & 2.14 & 4.29 & 0.09 & 0.055 \\
\hline & 100.10 & 100.15 & 100.13 & 98.17 & 98.46 & 99.38 \\
\hline$B a$ & 0.55 & 0.22 & 2.29 & 0.61 & 0.33 & 0.07 \\
\hline$L a$ & 1.00 & 1.30 & 0.27 & 0.06 & 1.20 & 0.16 \\
\hline $\mathrm{Ce}$ & 2.10 & 3.10 & 0.86 & 0.23 & 3.60 & 0.32 \\
\hline$P r$ & 0.33 & 0.39 & 0.18 & 0.03 & 0.53 & 0.06 \\
\hline$N d$ & 1.20 & 1.70 & 0.76 & 0.19 & 2.10 & 0.66 \\
\hline$E u$ & 0.04 & 0.05 & 0.08 & 0.05 & 0.11 & 0.59 \\
\hline$S m$ & 0.21 & 0.24 & 0.24 & 0.11 & 0.38 & 0.26 \\
\hline$G d$ & 0.19 & 0.10 & 0.26 & 0.17 & 0.27 & 1.61 \\
\hline$T b$ & 0.01 & 0.01 & 0.04 & 0.03 & 0.03 & 0.38 \\
\hline$D y$ & 0.07 & 0.03 & 0.21 & 0.14 & 0.13 & 3.90 \\
\hline Ho & 0.01 & 0.00 & 0.04 & 0.02 & 0.02 & 0.88 \\
\hline$E r$ & 0.01 & 0.01 & 0.10 & 0.06 & 0.04 & 2.50 \\
\hline$T m$ & 0.00 & 0.00 & 0.01 & 0.01 & 0.00 & 0.51 \\
\hline$Y b$ & 0.01 & 0.00 & 0.08 & 0.04 & 0.02 & 2.87 \\
\hline$L u$ & 0.00 & 0.00 & 0.01 & 0.01 & 0.00 & 0.52 \\
\hline$H f$ & 0.08 & 0.09 & 0.08 & 0.02 & 0.16 & 0.60 \\
\hline$T a$ & 0.00 & 0.01 & 0.02 & 0.01 & 0.01 & 0.07 \\
\hline $\mathrm{Pb}$ & 1.68 & 1.48 & 1.26 & 0.22 & 1.05 & 10.85 \\
\hline$T h$ & 1.20 & 0.90 & 0.51 & 0.09 & 0.16 & 0.46 \\
\hline U & 1.50 & 0.09 & 0.70 & 0.13 & 0.04 & 0.92 \\
\hline$S r$ & 202.04 & 278.50 & 60.90 & 2.70 & 438.00 & 0.00 \\
\hline$Y$ & 0.77 & 1.13 & 14.50 & 7.00 & 5.89 & 23.57 \\
\hline $\mathrm{Zr}$ & 22.65 & 30.97 & 85.95 & 27.95 & 71.16 & 21.88 \\
\hline $\mathrm{Nb}$ & 0.05 & 1.62 & 2.82 & 0.74 & 0.86 & 0.91 \\
\hline
\end{tabular}

